\title{
The Effect of Salinity on Growth, Antagonistic Potential, Protease Activity, and Proline Content of Trichoderma harzianum
}

\author{
Sedat ÇAM*, Çiğdem KÜÇÜK \\ ${ }^{1}$ Department of Biology, Harran University, Şanlıurfa, TURKEY \\ ORCID ID: Sedat ÇAM: https://orcid.org/0000-0001-9030-6713; Çiğdem KÜÇÜK: https://orcid.org/0000-0001-5688-5440
}

\begin{tabular}{llll}
\hline Received: 16.05 .2020 & Accepted: 16.06 .2020 & Published online: 27.06.2020 & Issue published: 29.06.2020
\end{tabular}

\begin{abstract}
Salinity is one of the major limiting factors for sustainable crop production and the growth of beneficial microorganisms. Screening of biocontrol agent Trichoderma harzianum isolates under saline conditions could be necessary to select more efficient strains to alleviate salt stress through biopriming in plants. The present study aimed to investigate the antagonistic capacity of $14 \mathrm{~T}$. harzianum isolates against Macrophomina phaseolina as well as the growth, protease activity, and proline content under different concentrations of salt. All isolates except Th15 and Th18 exhibited an over $85 \%$ inhibition against $M$. phaseolina at $0 \mathrm{mM} \mathrm{NaCl}$ in $\mathrm{c}$ and showed a noticeable decline in their antagonistic capacity as salt concentration increased. Colony growth decreased with increasing salt concentrations in all isolates tested. The growth of all isolates at 0 $\mathrm{mM}$ was significantly higher than the other $\mathrm{NaCl}$ treatments except at $70 \mathrm{mM} \mathrm{NaCl}$. Protease activity also declined with the increased level of salt. Isolates displayed a wide range of protease expression patterns even at the same salinity as in the case of proline content. Unlike protease enzyme, proline content significantly increased at $240 \mathrm{mM} \mathrm{NaCl}$. Salinity played a significant role in T. harzianum isolates with regards to the growth, antagonistic capacity, protease activity, and proline content.
\end{abstract}

Keywords: Biocontrol agent, Macrophomina phaseolina, lytic enzyme, phytopathogen.

\section{Tuzluluğun Trichoderma harzianum'un Büyüme, Antagonistik Potansiyeli, Proteaz Aktivitesi ve Prolin İçeriği Üzerindeki Etkisi}

Öz: Sürdürülebilir bitkisel üretimin artması ve faydalı mikroorganizmaların büyümesi için tuzluluk ana sınırlayıcı faktörlerden biridir. Biyokontrol ajanı olan Trichoderma harzianum izolatlarının tuzlu koşullar altında test edilmesi, biyopriming yoluyla bitkilerdeki tuz stresini hafifletmek için daha uygun suşlar seçmek gereklidir. Bu çalışmada, 14 T. harzianum izolatının Macrophomina phaseolina' ya karşı antagonistik kapasitesinin yanı sıra büyüme, proteaz aktivitesi ve prolin içeriği farklı tuz konsantrasyonları altında araştırıldı. Th15 ve Th18 dışındaki tüm izolatlar, ikili kültür analizinde $0 \mathrm{mM} \mathrm{NaCl'de} \mathrm{M}$. phaseolina'ya karşı \% 85'in üzerinde bir inhibisyon sergiledi ve tuz konsantrasyonu arttıkça antagonistik kapasitelerinde belirgin bir düşüş gösterdi. Test edilen tüm izolatlarda artan tuz konsantrasyonlarına bağlı olarak koloni büyümelerinde istatistiksel açıdan anlamlı azalmalar gözlemlendi. Tüm izolatların 0 mM'deki büyümesi, $70 \mathrm{mM} \mathrm{NaCl}$ hariç diğer $\mathrm{NaCl}$ uygulamalarında büyük ölçüde daha fazlaydı. Artan tuz seviyesi ile proteaz aktivitesi de azalmıştır. İzolatlar, prolin içeriğinde olduğu gibi aynı tuzlulukta bile farklı miktarlarda proteaz üretimi gösterdiler. Proteaz enziminin aksine, prolin içeriği $240 \mathrm{mM}$ NaCl'de önemli ölçüde artmıştır. Tuzluluk, T. harzianum izolatlarında büyüme, antagonistik kapasitesi, proteaz aktivitesi ve prolin içeriği bakımından önemli bir rol oynamıştır.

Anahtar kelimeler: Biyokontrol ajanı, Macrophomina phaseolina, litik enzim, fitopatojen.

\section{Introduction}

Biological control of plant pathogens offers an environmentally friendly alternative to chemical pesticides; thus, it has been increasingly becoming an important component in plant disease management (Kidwai \& Nehra, 2017). Several types of biological control agents are involved in biocontrol activity to suppress causative agents of various plant diseases and promote plant growth. It is welldocumented that Trichoderma spp., a genus of asexually reproducing filamentous fungi, is one of the most important biocontrol agents of several soil-borne plant pathogens. This fungus is a dominant component of fungal soil microbiota and exhibits varying levels of mycoparasitism against a wide range of plant pathogens and its biocontrol capability depends on specific strains rather than species (Kucuk \& Kivanc, 2003; Gajera \& Vakharia, 2012; Kidwai \& Nehra, 2017).

Differential antagonism of Trichoderma species against phytopathogen Macrophomina phaseolina has been well- studied (Etebarian, 2006; Khalili et al., 2016). M. phaseolina leads to charcoal rot disease, responsible for economically important yield losses in a variety of crop plants, and may infect the root of more than 500 plant species worldwide (Khalili et al., 2016). The variable severity of charcoal rot infestations is attributed to environmental changes such as water stress, drought, heat, and high temperatures (Singh, Pandey, Dubey, \& Maheshwari, 2008; Vinale et al., 2008; Khalili et al., 2016). Those studies ignored the effect of salt which is one of the major abiotic stresses limiting plant growth and yield (Rawat, Singh, Shukla, \& Kumar, 2011). The high incidence of charcoal rot disease might be the result of the elimination of biocontrol agents under adverse soil conditions such as high salinity. It was reported that tolerance of Trichoderma strains to salt is variable and salinity tolerant Trichoderma isolates could be more effective to increase crop productivity under salt stress (Rawat et al., 2011; Rawat, Singh, Shukla, \& Kumar, 2013)

Lytic enzymes are involved in the biocontrol activity of Trichoderma harzianum because such enzymes play an 
important role in the lysis of cell walls of filamentous plant pathogenic fungi during the antagonistic interaction. Proteolytic activity is a prerequisite to lysing whole fungal cells (Markovich \& Kononova, 2003). Moreover, the proteases produced by Trichoderma species may be involved in inactivating extracellular enzymes of phytopathogenic fungi (Markovich \& Kononova, 2003). T. harzianum isolates produce varying levels of proteases even under the same conditions. In a study, the proteolytic activity of two $T$. harzianum isolates was found to be significantly higher than that of the other strain under the same conditions (Marco, Valadares-Inglis, \& Felix, 2003).

Proline, an amino acid, plays several highly beneficial roles in plants under stress conditions and acts as an important osmolyte (Hayat et al., 2012). It also enables plants to maintain osmoregulation and recover from oxidative damage quickly (Ahmad et al., 2015); therefore, plants tend to accumulate more amount of free proline in response to different stress conditions. Besides stressful conditions, the other way of increasing proline content for plants is the inoculation of T. harzianum. Accumulation of proline content can be increased in plants inoculated with $T$. harzianum under both normal and stress conditions. It was reported that $T$. harzianum alone causes an increase of $32.08 \%$ in proline content while the inoculation of this fungus to drought-stressed plants increases by $80.8 \%$ (Mona et al., 2017). Similarly, an increase in proline content by inoculation of T. harzianum was also observed under $\mathrm{NaCl}$ stress (Ahmad et al., 2015).

The biocontrol and antifungal effects of different $T$. harzianum strains against plant pathogens differ from strain to strain and depend on ecological factors; therefore, the strains exhibit different behaviors based on the physiological tests (Kucuk \& Kivanc, 2003). In addition, to decrease the adverse effects of salinity and fungal diseases, screening salinity tolerant isolates would be necessary to select more efficient isolates to be used through biopriming to mitigate salt stress in plants (Rawat et al., 2011; Amaresan, 2016). The objectives of this study were to investigate antagonistic capacities of $14 \mathrm{~T}$. harzianum isolates against plant-pathogen $M$. phaseolina as well as to determine the growth, protease activity, and proline content under different salt concentrations.

\section{Materials and Methods}

\subsection{Isolation of Trichoderma harzianum spp.}

Approximately 420 soil samples were taken from cottonfarming regions of Harran province in Turkey. Serial dilutions were prepared from soil samples and inoculated onto petri dishes containing Martin's Rose Bengal Medium and Trichoderma Selective Medium. After a 5-day incubation period at $28{ }^{\circ} \mathrm{C}$, the colonies defined as Trichoderma were identified based on the colony and spore characteristics under the microscope (Kucuk \& Kivanc, 2003; Amaresan, 2016).

\subsection{Resistance of Trichoderma isolates to salt concentrations}

A 5-mm diameter disc of T. harzianum isolates was placed onto PDA containing different concentrations of $\mathrm{NaCl}(0,70$, $150,240,300,350 \mathrm{mM})$. The development of the isolates and spore formation in salt-containing agar plates were examined at $30^{\circ} \mathrm{C}$ during the 5-day incubation.

\subsection{Antagonistic activity of Trichoderma isolates}

Macrophomina phaseolina was used as a plant-pathogen. $T$. harzianum spp. and M. phaseolina obtained from soil were actively grown in sterile petri dishes containing PDA (Potato Dextrose Agar) at $25 \pm 2$ o $\mathrm{C}$ for 7 days. A 5-mm diameter disc of the selected $14 \mathrm{~T}$. harzianum isolates was inoculated onto PDA containing different concentrations $(0$, $70,150,240,300,350 \mathrm{mM}$ ) of $\mathrm{NaCl}$ with a 5 -mm diameter disc of plant-pathogen taken from actively growing colonies and incubated at $25 \pm 2{ }^{\circ} \mathrm{C}$ for 7 days. The distance between the inoculum of the isolates on the petri dishes was $5 \mathrm{~cm}$ (Kucuk \& Kivanc, 2003). The diameters of growth zones of the pathogen and antagonist fungus were measured and the percent inhibition of the growth was calculated by the formula (y-z / y) x 100 .

$\mathrm{y}=$ micelle development of the pathogen (in control petri dishes) (mm)

$\mathrm{z}=$ micelle development of the pathogen against antagonism of T. harzianum (mm)

\subsection{Protease activity}

The extracellular protease activity was performed based on the release of azo casein-based amino acids and small peptides in fungal culture. A 3-mm diameter disc of $T$. harzianum grown on PDA containing 0 and $240 \mathrm{mM} \mathrm{NaCl}$ was cut from the medium with the help of a cork-borer. The disc was removed with a pipette tip and placed in $1.5 \mathrm{~mL}$ Eppendorf tubes. $120 \mu \mathrm{L}(1 \% \mathrm{w} / \mathrm{v})$ azo-casein prepared in $50 \mathrm{mM}$ Tris- $\mathrm{HCl}$ ( $\mathrm{pH} 8.8$ ) was added to the tubes. Fungal growth and azo-casein hydrolysis were performed with incubation of tubes for an hour at room temperature. Protein breakdown (proteolysis) was terminated by adding $300 \mu \mathrm{L}$ $(10 \% \mathrm{w} / \mathrm{v})$ cold trichloroacetic acid (TCA). The aliquot was centrifuged at $15000 \mathrm{~g}$ for $10 \mathrm{~min} .350 \mu \mathrm{L}$ of supernatant was taken and mixed with $300 \mu \mathrm{L}$ of $1 \mathrm{M} \mathrm{NaOH}$. Afterward, the mixture was centrifuged at $15000 \mathrm{~g}$ for $10 \mathrm{~min}$ and the protease activity was measured on a $440 \mathrm{~nm}$ microplate reader (Sambrook, Fritsch, \& Maniatis, 1989; Haab, Hagspiel, Szakmary, \& Kubicek, 1990). Since the antagonistic activity was importantly declined at over 240 $\mathrm{mM} \mathrm{NaCl}$, we did not test protease activity and proline content at higher salinities.

\subsection{Determination of proline content}

Protein measurement was made according to the Coomassie Brilliant Blue G-250 method (Bradford, 1976). Micelles were collected by adding 8-10 mL sterile distilled water on the micelles of the isolates developed on PDA in petri dishes at $25 \pm 2{ }^{\circ} \mathrm{C}$ for 7 days. The isolates were grown on PDA supplemented with 0 and $240 \mathrm{mM} \mathrm{NaCl}$ for the estimation of proline content. The collected micelle mass was homogenized in phosphate buffer $(\mathrm{pH} 7)$ and centrifuged for $10 \mathrm{~min}$ at $10000 \mathrm{~g}$. The protein content of the supernatant obtained was determined according to Bradford (1976). 2 $\mathrm{mL}$ of the supernatant obtained from protein extracts was mixed with a $2 \mathrm{~mL}$ ninhydrin solution (1.25 ninhydrin, 30 $\mathrm{mL}$ of acetic acid, and $20 \mathrm{~mL}$ of $6 \mathrm{M}$ phosphoric acid) and boiled at $80{ }^{\circ} \mathrm{C}$ for $55-60 \mathrm{~min}$. The reaction was terminated by keeping the samples on ice and proline was separated by adding $5 \mathrm{~mL}$ of toluene. After $15-20 \mathrm{~min}$, the content was separated into 2 different phases and measured at $520 \mathrm{~nm}$ using a UV-Vis spectrophotometer. Proline concentration was determined using calibration curve. L-proline solution 
was used as a standard (Bates, Waldren, \& Teare, 1973).

\subsection{Statistical analysis}

Before one-way ANOVA, Bartlett's test was used to test for equality of variances. Bonferroni post hoc test was employed for the growth and antagonistic activity results $(\mathrm{P}<0.05)$ and a two-sample t-test was conducted for protease activity and proline content experiments to determine differences in means $(\mathrm{P}<0.05)$ in SPSS.

\section{Results and Discussion}

Most plants are sensitive or moderately sensitive to salinity. Among several methods employed to improve plant growth and productivity in salty environments, inoculation of salinity tolerant Trichoderma strains through seed biopriming proved to be an effective strategy in inducing salt tolerance (Rawat et al., 2011). Therefore, we tested the growth and antagonistic effect of $T$. harzianum isolates as well as protease activity and proline content under different concentrations of salt.

A total of $14 T$. harzianum strains were isolated from cotton-farming regions of Harran province in Turkey. These isolates were screened for their growth and spore-formation ability under different salt concentrations. The results revealed that the growth of all these isolates was decreased with increasing salt concentration (Table 1). The best colony growth was observed at $0 \mathrm{mM} \mathrm{NaCl}$. Bonferroni post hoc test analysis showed that the growth at $0 \mathrm{mM} \mathrm{NaCl}$ in all isolates was significantly higher than the other $\mathrm{NaCl}$ treatments except at $70 \mathrm{mM}(\mathrm{P}<0.05)$. Spore production was observed only at higher salt concentrations by some isolates (Table 1). Similar to the results of our experiments, the other researchers demonstrated that salt appeared to have a significant negative impact on the mycelial growth of $T$. harzianum isolates (Kredics, Antal, \& Manczinger, 2000; Rawat et al., 2013; Amaresan, 2016). Salt amendments led to a progressive drop in mycelial growth of Trichoderma isolates. Rawat et al. (2013) revealed that of 45 T. harzianum isolates, only five isolates were salinity tolerant and able to grow and sporulate up to $240 \mathrm{mM} \mathrm{NaCl}$. However, our results showed that $T$. harzianum isolates were able to grow and sporulate in the growth medium containing up to 350 $\mathrm{mM}$ salt. This may be due to strain differences.

Table 1. Growth of T. harzianum isolates at different levels of salinity

\begin{tabular}{ccccccc}
\hline \multicolumn{7}{c}{ Colony growth $(\mathrm{cm})$} \\
\hline Strains & 0mM & $70 \mathrm{mM}$ & $150 \mathrm{mM}$ & $240 \mathrm{mM}$ & $300 \mathrm{mM}$ & $350 \mathrm{mM}$ \\
\hline Th1 & 9.2 & 8.6 & 8.5 & 7.6 & 6.2 & 3.5 \\
Th2 & 9.1 & 8 & 7.6 & 7.4 & 6 & 2.5 \\
Th3 & 9 & 8.3 & 8 & 7.4 & 7.3 & 7.2 \\
Th4 & 9.2 & 9 & 8.6 & 8 & $8^{*}$ & 6.2 \\
Th5 & 9 & 8.2 & 8 & 7.7 & $7.1^{*}$ & $5.8^{*}$ \\
Th6 & 9.1 & 8.7 & 8 & 7.5 & 6.7 & $5.8^{*}$ \\
Th7 & 9.2 & 9 & $8.6^{*}$ & 7.9 & $7.8^{*}$ & 7.5 \\
Th8 & 9.2 & 9 & 8 & 7.9 & 7.6 & 7.4 \\
Th9 & 8.8 & 7.4 & $7.2^{*}$ & 6.9 & $5.2^{*}$ & $4.4^{*}$ \\
Th13 & 8.9 & 8.2 & 8 & 7.8 & 7.8 & 6.5 \\
Th14 & 9.2 & 8.8 & $8.2^{*}$ & 7.1 & $6.6^{*}$ & 5.5 \\
Th15 & 8.9 & 7.8 & 7.1 & 7 & $6.8^{*}$ & 6.4 \\
Th17 & 9 & 8 & 7.7 & 7.5 & 7 & $5.4^{*}$ \\
Th18 & 8.8 & 5.9 & 5.7 & 5.1 & 4.6 & $4.3^{*}$ \\
\hline
\end{tabular}

* denotes spore production

The antagonistic capacity of $T$. harzianum strains against phytopathogen Macrophomina phaseolina was also tested under different saline conditions in dual cultures. The greatest percent inhibition was observed at $0 \mathrm{mM} \mathrm{NaCl}$
(Table 2). All the isolates showed an over $85 \%$ inhibition at $0 \mathrm{mM} \mathrm{NaCl}$ against the pathogen except two isolates (Th15 and Th18). The inhibition rate was correlated with increasing salt concentrations. An increase in $\mathrm{NaCl}$ concentration consistently decreased the percent pathogen inhibition in all the isolates tested (Table 2). The present result is in good agreement with that obtained by the studies (Kredics et al., 2000; Rawat et al., 2013) indicating that the antagonistic capacity of T. harzianum against phytopathogen Fusarium oxysporum was reduced with increasing salinity and tends to disappear at higher levels of salt. The salinity tolerant isolates revealed significantly greater antagonistic capacity against the plant-pathogen on saline medium compared to the salinity sensitive strains (Rawat et al., 2013). Similar observations were also made against Rhizoctonia solani (Kashyap, Solanki, Kushwaha, Kumar, \& Srivastava, 2020).

Table 2. Percent pathogen inhibition of T. harzianum isolates at different levels of salinity

\begin{tabular}{ccccccc}
\hline \multicolumn{7}{c}{ Pathogen inhibition (\%) } \\
\hline Strains & 0mM & $70 \mathrm{mM}$ & $150 \mathrm{mM}$ & $240 \mathrm{mM}$ & $300 \mathrm{mM}$ & $350 \mathrm{mM}$ \\
\hline Th1 & 86.1 & 86.1 & 84.7 & 79.2 & 69.4 & 27.5 \\
Th2 & 85 & 80 & 75.1 & 68 & 62.2 & 22.2 \\
Th3 & 96 & 86.1 & 85.4 & 84.7 & 53.6 & 51.8 \\
Th4 & 90.3 & 85.7 & 80.4 & 78.6 & 62.1 & 55.8 \\
Th5 & 87.7 & 87.5 & 72.2 & 70 & 68.7 & 52.6 \\
Th6 & 88.9 & 86.7 & 77.5 & 72 & 60.8 & 51.2 \\
Th7 & 91.7 & 86.1 & 83.3 & 81.9 & 53.6 & 43.7 \\
Th8 & 88.9 & 87.5 & 84.7 & 79.2 & 69 & 44.6 \\
Th9 & 88 & 86 & 80 & 75 & 56.5 & 38.5 \\
Th13 & 87 & 84.3 & 83.7 & 81.9 & 62.2 & 47.4 \\
Th14 & 90.3 & 86.1 & 84.7 & 83.2 & 42.2 & 33.7 \\
Th15 & 54.7 & 50.6 & 49.2 & 41.7 & 38.8 & 27.2 \\
Th17 & 86.1 & 84.7 & 83.6 & 78.6 & 53.2 & 47.4 \\
Th18 & 53.3 & 51.9 & 48.4 & 46.2 & 44.9 & 39.7 \\
\hline
\end{tabular}

The protease activity of the biocontrol agent $T$. harzianum isolates in media supplemented with different concentrations of salt is shown in Table 3. Protease productions by all the isolates were negatively correlated with an increase in salt concentration. The highest protease activity was observed at $0 \mathrm{mM}$ compared to $240 \mathrm{mM} \mathrm{NaCl}$ in all the isolates. Protease production of the isolates at 0 $\mathrm{mM} \mathrm{NaCl}$ was significantly higher than those at $240 \mathrm{mM}$ (two-sample t-test, $\mathrm{P}<0.001$ ). The isolates tested showed a wide range of protease activities, ranging from 12.4 to 28.1 $\mathrm{U} \mathrm{mg}^{-1}$ and from 4.7 to $14.8 \mathrm{U} \mathrm{mg}^{-1}$ (at 0 and $240 \mathrm{mM} \mathrm{NaCl}$, respectively). The maximum levels of protease (28.1 and $14.8 \mathrm{U} \mathrm{mg}^{-1}$ ) were produced by Th14 (at 0 and $240 \mathrm{mM} \mathrm{NaCl}$, respectively) (Table 3). As in the case of our study, Marco et al. (2003) reported that $T$. harzianum isolates produce different amounts of proteases under the same conditions. In addition, similar to the current study, a recent study revealed that Trichoderma isolate produces varying levels of proteases at different salinities and protease activity is declined with the increased level of salt stress from 0 to 250 $\mathrm{mM} \mathrm{NaCl}$ (Kashyap et al., 2020). It is well-established that proteases are involved in competition for protein substrates, in inactivating extracellular enzymes of phytopathogenic fungi as well as in the mycoparasitism by degrading the protein components of the cell wall of fungal pathogens (Markovich \& Kononova, 2003; Kredics et al., 2005; Gajera \& Vakharia, 2012). In literature, the previous investigations ignored the effect of salinity on proteolytic activity except Kashyap et al. (2020) who worked with only one Trichoderma isolate, which required the necessity to investigate more isolates. 
Table 3. Protease activity and proline content of T. harzianum isolates at different levels of salinity

\begin{tabular}{ccccc}
\hline & Protease activity $\left(\mathrm{U} \mathrm{mg}^{-1}\right)$ & \multicolumn{2}{c}{ Proline content $\left(\mu \mathrm{moles}^{-1}\right)$} \\
\hline Strains & 0mM & $240 \mathrm{mM}$ & $0 \mathrm{mM}$ & $240 \mathrm{mM}$ \\
\hline Th1 & 20.7 & 8.1 & 0.12 & 6.52 \\
Th2 & 19.9 & 12.8 & 0.06 & 7.06 \\
Th3 & 24.8 & 14.1 & 0.13 & 7.05 \\
Th4 & 23.4 & 8.3 & 0.08 & 8.48 \\
Th5 & 12.4 & 10.3 & 0.11 & 6.51 \\
Th6 & 16.5 & 9.7 & 0.10 & 6.17 \\
Th7 & 16.7 & 13.8 & 0.12 & 8.13 \\
Th8 & 14.8 & 11 & 0.09 & 7.87 \\
Th9 & 17.3 & 7.3 & 0.12 & 5.98 \\
Th13 & 26.8 & 10.2 & 0.08 & 9.06 \\
Th14 & 28.1 & 14.8 & 0.16 & 7.27 \\
Th15 & 27.9 & 10.3 & 0.09 & 10.08 \\
Th17 & 20.5 & 10.8 & 0.14 & 7.19 \\
Th18 & 12.6 & 4.7 & 0.06 & 6.96 \\
\hline
\end{tabular}

Proline plays an important role in ROS scavenging and maintaining osmoregulation in plants (Ahmad et al., 2015). It also protects metabolic processes under adverse conditions by replacing water, thus keeping the stability of important cellular structures (Zhifang \& Loescher, 2003). To increase proline content, plants are inoculated with Trichoderma isolates. Previous studies reported that total proline content in plants could be increased with Trichoderma treatments and the contribution of proline accumulation differs in the isolates (Rawat et al., 2011; Rawat, Bisht, Upadhayay, \& Kukreti 2016; Mona et al., 2017; Yasmeen \& Siddiqui, 2017). In these studies, some strains significantly increased total proline content in mycelia cells while other isolates could not exhibit significant effects. Similarly, our result showed that the strains displayed a wide range of proline production at both salinities. The proline content of the isolates ranged from 0.06 to $0.16 \mu \mathrm{mol}$ $\mathrm{g}^{-1}$ at $0 \mathrm{mM}$ and from 5.98 to $10.08 \mu \mathrm{mol} \mathrm{g}^{-1}$ at $240 \mathrm{mM} \mathrm{NaCl}$ (Table 3). This variability in proline production of different isolates might explain more or less accumulation of proline in plants treated with Trichoderma strains. Proline content of the isolates at $240 \mathrm{mM} \mathrm{NaCl}$ was found to be significantly higher than those at $0 \mathrm{mM}$ (two-sample t-test, $\mathrm{P}<0.001$ ).

In conclusion, higher salinity appeared to have a significant negative effect on the growth, antagonistic capacity, and protease activity of T. harzianum isolates but significantly increased proline content. The isolates responded differently to the tested parameters. We suggest here that the salinity parameter should be taken into consideration when working with T. harzianum isolates with regards to the growth, antagonistic potential, protease activity, and proline content.

\section{References}

Ahmad, P., Hashem, A., Alqarawi, A., John, R., Egamberdieva, D., \& Gucel, S. (2015). Role of Trichoderma harzianum in mitigating $\mathrm{NaCl}$ stress in Indian mustard (Brassica juncea L) through antioxidative defense system. Frontiers in Plant Science, 6, 868. https://doi.org/10.3389/fpls.2015.00868

Amaresan, N. (2016). Influence of salt tolerant Trichoderma spp. on growth of maize (Zea mays) under different salinity conditions. Journal of Basic Microbiology, 57, 141-150. https://doi.org/10.1002/jobm.201600369

Bates, L.S., Waldren, R.P., \& Teare, I.D. (1973). Rapid determination of free proline for water-stress studies. Plant and Soil, 39, 205-207. https://doi.org/10.1007/BF00018060

Bradford, M.M. (1976). A rapid and sensitive method for the quantitation of microgram quantities of protein utilizing the principle of protein-dye binding. Analytical Biochemistry, 72, 248-254. https://doi.org/10.1016/0003-2697(76)90527-3

Etebarian, H.R. (2006). Evaluation of Trichoderma isolates for biological control of charcoal stem rot in Melon caused by Macrophomina phaseolina. Journal of Agricultural Science, 8, 243-250. https://doi.org/10.1080/13102818.2016.1147334

Gajera, H.P., \& Vakharia, D.N. (2012). Production of lytic enzymes by Trichoderma isolates during in vitro antagonism with Aspergillus niger, the causal agent of collar rot of peanut. Brazilian Journal of Microbiology, 43, 43-52. http://dx.doi.org/10.1590/S1517-83822012000100005

Haab, D., Hagspiel, K., Szakmary, K., \& Kubicek, C.P. (1990). Formation of the extracellular proteases from Trichoderma reesei QM 9414 involved in cellulase degradation. Journal of Biotechnology, 16, 187-198. https://doi.org/10.1016/0168-1656(90)90035-A

Hayat, S., Hayat, Q., Alyemeni, M.N., Wani, A.S., Pichtel, J., \& Ahmad, A. (2012). Role of proline under changing environments: a review. Plant Signaling and Behavior, 7, 1456-1466. https://doi.org/10.4161/psb.21949

Kashyap, P.L., Solanki, M.K., Kushwaha, P., Kumar, S., \& Srivastava, A.K. (2020). Biocontrol potential of salt-tolerant Trichoderma and Hypocrea isolates for the management of tomato root rot under saline environment. Journal of Soil Science and Plant Nutrition, 20, 160-176.

Khalili, E., Javed, M.A., Huyop, F., Rayatpanah, S., Jamshidi, S., \& Wahab, R.A. (2016). Evaluation of Trichoderma isolates as potential biological control agent against soybean charcoal rot disease caused by Macrophomina phaseolina. Biotechnology and Biotechnological Equipment, 30, 479-488. https://doi.org/10.1080/13102818.2016.1147334

Kidwai, M.K., \& Nehra, M. (2017). Biotechnological Applications of Trichoderma Species for Environmental and Food Security. In Gahlawat S., Salar R., Siwach P., Duhan J., Kumar S., \& Kaur P. (Eds.), Plant Biotechnology: Recent Advancements and Developments (pp. 125-156). Singapore, Springer press.

Kredics, L., Antal, Z., \& Manczinger, L. (2000). Influence of water potential on growth, enzyme secretion and in vitro enzyme activities of Trichoderma harzianum at different temperatures. Current Microbiology, 40, 310-314. https://doi.org/10.1007/s002849910062

Kredics, L., Antal, Z., Szekeres, A., Hatvani, L., Manczinger, L., ... \& Nagy, E. (2005). Extracellular proteases of Trichoderma species. Acta Microbiologica et Immunologica Hungarica, 52, 169-184.

Kucuk, C., \& Kivanc, M. (2003). Isolation of Trichoderma spp. and determination of their antifungal, biochemical and physiological features. Turkish Journal of Biology, 27, 247-253.

Marco, J.L.D., Valadares-Inglis, M.C., \& Felix, C.R. (2003). Production of hydrolytic enzymes by Trichoderma isolates with antagonistic activity against Crinipellis perniciosa, the causal agent of witches' broom of cocoa. Brazilian Journal of Microbiology, 34, 33-38. http://dx.doi.org/10.1590/S1517-83822003000100008

Markovich, N.A., \& Kononova, G.L. (2003). Lytic enzymes of Trichoderma and their role in plant defense from fungal diseases: A review. Applied Biochemistry and Microbiology, 39, 341-351. https://doi.org/10.1023/A:1024502431592

Mona, S.A., Hashem, A., Abd_Allah, E.F., Alqarawi, A.A., Soliman, D.W.K., ...\& Egamberdieva, D. (2017). Increased resistance of drought by Trichoderma harzianum fungal treatment correlates with increased secondary metabolites and proline content. Journal of Integrative Agriculture, 16, 1751-1757. https://doi.org/10.1016/S20953119(17)61695-2

Rawat, L., Bisht, T., Upadhayay, R., \& Kukreti, A. (2016). Trichoderma harzianum enhancing plant growth parameters and reducing deleterious effects of natural saline-sodic soil in Rice. National Academy of Agricultural Science, 34(6), 1855-1867

Rawat, L., Singh, Y., Shukla, N., \& Kumar, J. (2011). Alleviation of the adverse effects of salinity stress in wheat (Triticum aestivum L.) by seed biopriming with salinity tolerant isolates of Trichoderma harzianum. Plant and Soil, 347, 387. https://doi.org/10.1007/s11104-011-0858-z

Rawat, L., Singh, Y., Shukla, N., \& Kumar, J. (2013). Salinity tolerant Trichoderma harzianum reinforces $\mathrm{NaCl}$ tolerance and reduces population dynamics of Fusarium oxysporum f.sp. ciceri in chickpea (Cicer arietinum L.) under salt stress conditions. Archives of Phytopathology and Plant Protection, 46, 1442-1467. https://doi.org/10.1080/03235408.2013.769316

Sambrook, J., Fritsch, E.F., \& Maniatis, T. (1989). Molecular cloning: a laboratory manual. Cold Spring Harbor, NY, Cold Spring Harbor Laboratory Press.

Singh, N., Pandey, P., Dubey, R.C., \& Maheshwari, D.K. (2008). Biological control of root rot fungus Macrophomina phaseolina and growth enhancement of Pinus roxburghii (Sarg.) by rhizosphere competent Bacillus subtilis BN1. World Journal of Microbiology and Biotechnology, 24, 1669-1679. https://doi.org/10.1007/s11274-008-9680-z

Vinale, F., Sivasithamparam, K., Ghisalberti, E., Marra, R., Woo, S., \& Lorito, M. (2008). Trichoderma-plant-pathogen interactions. Soil Biology and Biochemistry, 40, 1-10. https://doi.org/10.1016/j.soilbio.2007.07.002 
Yasmeen, R., \& Siddiqui, Z.S. (2017). Physiological responses of crop plants against Trichoderma harzianum in saline environment. Acta Botanica Croatica, 76(2), 154-162. https://doi.org/10.1515/botcro-2016-0054

Zhifang, G., \& Loescher, W.H. (2003). Expression of a celery mannose 6phosphate reductase in Arabidopsis thaliana enhances salt tolerance and induces biosynthesis of both mannitol and a glucosyl-mannitol dimer.
Plant,
Cell and Environment
26 ,
275-283. 